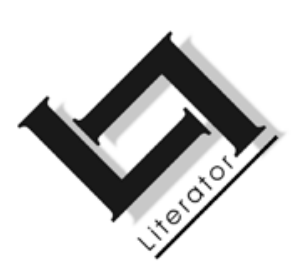

\title{
Daring to disturb the universe: Heidegger's authenticity and The love song of J. Alfred Prufrock
}

\author{
D. Griffiths
}

Department of Philosophy

University of Pretoria

PRETORIA

E-mail: dgri051@aucklanduni.ac.nz

\section{Abstract \\ Daring to disturb the universe: Heidegger's authenticity and The love song of J. Alfred Prufrock}

In Heidegger's "Being and time" certain concepts are discussed which are central to the ontological constitution of "Dasein". This article demonstrates the interesting way in which some of these concepts can be used in a reading of T.S. Eliot's "The love song of J. Alfred Prufrock". A comparative analysis is performed, explicating the relevant Heideggerian terms and then relating them to Eliot's poem. In this way strong parallels are revealed between the two men's respective thoughts and distinct modernist sensibilities. Prufrock, the protagonist of the poem, and the world he inhabits illustrate poetically concepts such as authenticity, inauthenticity, the "they", idle talk and angst, which Heidegger develops in "Being and time".

\section{Opsomming}

Die heelal durf versteur: outentisiteit by Heidegger en in the love song of J. Alfred Prufrock

In "Being and time" bespreek Heidegger sekere konsepte wat sentraal staan tot die ontwikkeling van sy idees rondom "Dasein". Hierdie artikel ontleed die ontheemde manier waarop sommige van hierdie konsepte gebruik kan word in ' $n$ interpretasie van T.S. Eliot se werk "The love song of J. Alfred Prufrock". In 'n vergelykende studie word die betrokke Heideggeriaanse terme eers uiteengesit en daarna in verband gebring met Eliot se gedig. Op hierdie wyse word sterk parallelle getrek 
tussen Heidegger en Eliot se denke en bepaalde modernistiese kwessies. Prufrock, die protagonis van die gedig, en die wêreld wat hy bewoon bied 'n illustrasie van konsepte soos outentisiteit, inoutentisiteit, die "hulle" ("they" of "das Man"), ydele geklets en angs, wat Heidegger in "Being and time" ontwikkel.

\section{Introduction}

T.S. Eliot (1888-1965) and Martin Heidegger (1889-1976) occupy profoundly important positions in twentieth-century literature and philosophy. For both, great poetry is the highest form of human endeavour. Eliot abandoned a possible career as perhaps a minor but talented philosopher at Harvard University in favour of the uncertain struggle to attain recognition as a poet in London. This he achieved beyond measure and his poetry and critical prose have become firmly established in the canon of great Western literature. Heidegger dabbled a little in poetry, but it is his philosophical insights into the relationship between language and poetry and the philosophical dialogues he maintained with Rilke, Celan, Trakl and especially Hölderlin that demonstrate his high regard for poetry. Hölderlin remained his favourite and the poet's phrase "poetically man dwells" (Heidegger, 2001:211) is arguably the cornerstone to Heidegger's later philosophy. This shared concern for poetry is one of the many ideas Heidegger and Eliot have in common and has its roots in both men's thorough immersion in mastery of the history of philosophy, their disillusionment with modernity, and the fact that they lived through the same tumultuous period of history. Though neither directly influenced the other, a fruitful and largely unexplored dialogue between Eliot and Heidegger in terms of echoed sentiments is possible. The aim of this article is to explore one such sentiment.

Eliot and Heidegger never met one another, although Eliot, in 1932, writes the following in one of his commentaries in his journal The criterion:

It is greatly to the credit of the intellectuals of post-War Germany, living in a country which has been more politics-ridden than any other of Western Europe, and in an atmosphere which one might suppose most discouraging to dispassionate thought, that they have been able to produce so much that is first rate. It is a pity that work of this kind finds little appreciation in England; the spring comes slowly up our way, and modern Germany is only known by some of its novels and by a few books of topical interest. Writers of more permanent importance than Spengler are unknown. Such names as those of Heidegger in philosophy 
and Heim in theology are known to only a handful; Friedrich Gundolf and Max Scheler are slightly known to some of our readers. (Eliot, 1967:73.)

This passage indicates that Eliot had not only heard of Heidegger but was also aware that he was becoming well known in philosophy circles internationally. Arendt writes that as early as 1919, when Heidegger was only a Privatdozent (instructor) at the University of Freiburg, his reputation as a teacher travelled across Germany "like the rumour of the hidden king" (Van Buren, 1994:3). With the publication of Being and time (Sein und Zeit) in 1927 in Husserl's Jahrbuch, Heidegger established his international reputation as a philosopher and solidified his early academic career (Caputo, 1999:225).

As a trained professional philosopher, Eliot was thus attuned to significant philosophical developments on the continent. He was taught philosophy at Harvard by the likes of Santayana, Babbitt and Royce; according to Bertrand Russell, until the Harvard School of Philosophy lost the services of men such as these, it was the best in the world (Jain, 2004:62). Eliot wrote his Ph.D. thesis on the philosophy of F.H. Bradley and completed it in 1916.1 In the context of this article it is also important to mention that Eliot read Husserl's Logical investigations (1900) while at Marburg in 1914. His comment to a friend was that he found it terribly hard, but very interesting (Jain, 2004:291). Schwartz (1985:9) points out that Eliot's famous term, "objective correlative", appears first in Husserl's book and that Eliot's early philosophical papers indicate that he knew exactly what he was doing when he lifted the term from Husserl. Husserl was, of course, Heidegger's teacher and a formative influence on his philosophical development. So though we have no direct evidence that Eliot ever read Heidegger, or vice versa, we can certainly say they were familiar with the same general fields of philosophic thought.

There is a great deal of scholarship on Eliot and his relationship to philosophy. Perhaps the most helpful starting point is an overview of this material in Childs's book, From philosophy to poetry: T.S. Eliot's study of knowledge and experience (2001). There is also scholar-

1 However, he never turned to Harvard for his oral defence and was thus never officially awarded the degree. The text is published as Knowledge and experience in the philosophy of F.H Bradley (Eliot, 1964). Commentators have speculated that Eliot never returned because of the pressure of his family's expectation that he assume the respectable role of a professor at Harvard, rather than that of a poet in London, a pressure he was determined to avoid (e.g. see Seymour-Jones, 2001:103). 
ship on Heidegger and his relationship with literature, for example the book edited by Spanos: Martin Heidegger and the question of literature: toward a postmodern literary hermeneutics (1979). However, very little scholarship concentrates on the relationship between Heidegger and Eliot. Yet, as I hope to show, both share numerous concerns and prejudices which are worth investigating. 2 This article explores one simple example, a common perception and reading of the condition of early twentieth-century Western society, found in Eliot's The love song of J. Alfred Prufrock (written in 1911, first published in The Egoist in 1915), and in Heidegger's Being and time (1927).

Much of T.S. Eliot's poetry can be fruitfully interpreted using Heidegger's ontological analysis of human existence. ${ }^{3}$ The love song of $\mathrm{J}$. Alfred Prufrock yields particularly rich results, which is why I have chosen it for the focus of this article. Heidegger's concepts of authenticity (Eigentlichkeit), inauthenticity (Uneigentlichkeit), the "they" (das Man), "idle talk" (Gerede) and angst (Angst), which are developed in Being and time, illuminate ontological, existential concerns which Eliot's poem strongly suggests, and which revolve around the question of authenticity. Section 2 of this article explores the idea of the "they", defining it and then relating it to Prufrock. Section 3 discusses the related concept of "idle talk", and examples of it in the poem. Finally, section 4 explores "angst", the psychological condition of the individual in the modern world, in Heidegger's philosophy and in the poem. In conclusion I will briefly suggest how this small project in comparing some aspects of Eliot and Heidegger has scope for a wider investigation of the patterns of concordance and echoed sentiment which bridge their separate projects.

2 Jain's book (2004) is helpful as well as material in The Cambridge companion to T.S. Eliot (1994) edited by A. David Moody, particularly the articles by Shusterman (1994) and Rabaté (1994). Hay (1982) offers some brief, interesting points of intersection which are not developed. Two excellent articles, one by Spanos (1978) and one by Wilson (1995), offer interesting readings on Eliot's Four quartets. The reader is advised to avoid Davidson's book (1985) which is a poorly executed and largely incoherent account of Heidegger's philosophy.

See Spanos (1979) for example. 


\section{The "they" (Das Man)}

In Being and time, Heidegger (1996:107) writes that "initially, and for the most part, Dasein is taken in by its world". 4 It finds itself thrown (Geworfen) into a particular world, in which it is mostly immersed. Each of us as Dasein cannot choose the initial, particular circumstances of its existence in this world as these are ontological determinations beyond its control. However, Dasein mostly remains unaware of this thrownness. Its primary constitution is as a being-inthe-world, an average state of immersion, characterised as its everyday mode of being.

Heidegger describes this mode as inauthentic and discusses various existentials which contribute to and maintain it. 5 One of these he calls the "they" (Das Man). The term is used in our everyday idiom, in phrases like "They say that ...". Heidegger attempts to determine who, exactly, the "they" are and what their influence is. He argues that the "they" implies no one and yet everyone, embodying the masses, the faceless body of society in general. The "they" are the source and site of accepted, acceptable public opinion, and so exert an anonymous pressure on each of us to conform to the dictates of our society. It is the "they" that "prescribes the kind of being of everydayness (Alltäglichkeit)" (Heidegger, 1996:118-119). In its everyday mode of living, Dasein is immersed in this everyday world of the "they".

But to what real world society does this apply? Fritsche (1999:15) argues that the idea of the "they" applies only in Heidegger's immediate context, namely the Weimar-era urban centres in Germany, then undergoing a rapid loss of tradition and culture. Schatzki (2005:243) disagrees, broadening the scope; he says the "they" "seem peculiarly keyed to early twentieth-century public life in

4 The term Dasein is central in Heidegger's earlier work. It is literally translated as "being-there". The term indicates the being capable of recognising its thereness, namely human beings.

In Being and time Heidegger makes an important distinction between existential and existentiell. An existential is an essential ontological attribute that Dasein has, something which constitutes it as Dasein. Examples could be that Dasein is always a being towards death or in the case of this discussion, that Dasein is constituted as being among the "they". This is Dasein's general predisposition. The modification of Dasein's orientation towards these ontological existentials is referred to as an existentiell. Thus my existential disposition is to be inauthentic among the "they"; modifying my disposition to authenticity is an existentiell. (Gorner, 2007:110). 
Germany and northern Europe". Even more broadly, Young (1997: 199) reads the "they" as applying to the full sweep of human culture, as an "omnitemporal 'existential'", which is also how Heidegger, given his overall intention in Being and time, intended the "they" to be understood. 6 These commentators' underlying point is that the phenomenon of the "they" is a result of humans' existing together, and that it is specifically keyed towards ensuring their conformity in a society. For the purposes of my argument I will orientate my reading in line with Schatzki and Young's. As Dasein every human person lives his/her life in the world of the "they" and is largely shaped by and immersed in this world.

The danger with this immersed state is that Dasein can forget its own self-being, that is, disregard the possibility of recognising its own individuated existence. It can become entirely formed by and part of the "they"-self of everydayness. Because its initial state of being, before it has come to terms with its own self, is among the "they". Dasein's identity is already significantly formed by the context and circumstances created by the "they". This formation of identity occurs preconceptually, so inauthenticity is inevitable and unavoidable, because Dasein is firstly a being with others in a shared world. Thus a certain kind of subservience to the "they" is inevitable, but it can also be existentially problematic.

The first problem with the "they-self" is that Dasein may never discover its own authentic self, if it remains embedded in and controlled by the dictates of the "they".

This in turn leads to the second problem, which is the reduction of the possibilities of its own existence, because all its choices are limited and moulded according to the whims and desires of the "they". This further solidifies its inauthenticity because it limits the possibilities of each Dasein to those of the "they" only. The averageness that permeates the "they" prevents Dasein from realising its own authenticity. As an inauthentic Dasein the individual stands "in subservience to the others. It itself is not; the others have taken

6 Young points out that a great deal of Foucault's philosophy reads as an exploration of Heidegger's "they". For Foucault "normalization" is a key process produced specifically as a result of Enlightenment thinking. Young (2003:177) writes that this process of "normalization" is not portrayed in Heidegger's discussion of the "they" - which is presented as an ahistorical phenomenon present in all human societies - but rather as "the dark under-belly of the Enlightenment", which for Foucault entails the disciplines and techniques of normalisation. 
its being away from it. The everyday possibilities of the being of Dasein are at the disposal of the whims of the others" (Heidegger, 1996:118). Each individual, under the "spell" of the "they", is "levelled down" according to their prescribed dictates. This ensures that all behaviour conforms to societal norms. This "levelling down" occurs because the "they" already presents each Dasein with specific, ready-made, acceptable moulds, opinions and attitudes that are deemed correct, to ensure the well-being of the "they" as a totality. Thus the "they" disburdens Dasein in its everydayness because, having being levelled down, it never faces the responsibility of its own choice. Rather, it can always find recourse from itself in the unanimity of the "they" and be disburdened from itself. The immediacy and perplexity of its own existence is lost and covered over by allowing the "they" to remove its responsibility for being (Heidegger, 1996:120). This mode of being Heidegger characterises as inauthentic and also as fallen (Verfallen) (Inwood, 1999:65).

However, inauthenticity "does not signify a lessening of the facticity of Dasein". In the mode of inauthenticity, Dasein is not less real nor somehow deficient compared to Dasein in the mode of authenticity. Both these modes form part of the ontological constitution of our being-in-the-world. Heidegger asserts that "the they is an existential and belongs as a primordial phenomenon to the positive constitution of Dasein". Arguably the "they" is positive, because through Dasein's grasp of its own inauthentic "they"-self, it may come to realise its own authentic self.

This authentic self Heidegger (1996:120-121) defines initially as "the self which has explicitly grasped itself". 7 To become authentic Dasein must break out of the limitations of the "they-self".

If Dasein explicitly discovers the world and brings it near, if it discloses its authentic being to itself, this discovering of 'world' and disclosing of Dasein always comes about by clearing away coverings and obscurities, by breaking up the disguises with which Dasein cuts itself off from itself. (Heidegger, 1996:121.)

$7 \quad$ Safranski (1999:165) gives a succinct explanation of authenticity which is useful for the discussion of The love song of J. Alfred Prufrock:

Dasein is authentic when it has the courage to base itself on itself ... when it can dispense with the unburdening offers on the part of the world of They; when it finds the strength to bring itself back from 'being lost'; when it no longer toys with the thousand possibilities existing but instead seizes the possibility that one is oneself. 
If Dasein can recognise itself, that is, its own existence as unique and finite, and moves beyond needing the assertions of the "they", then it will disclose its own authentic being. Carman (2007:285) describes authenticity as follows: "Authentic modes of existence ... are those in which Dasein stands in a directly first-person relation to itself in contrast to second- and third-person relations in which it stands to others." The authentic person as Dasein, in Heidegger's terms, grasps its own existence as "mineness" (Jemeinigkeit). It achieves its capacity for genuine individuality (Mulhall, 1996:131).

Through the disclosing of the world and the "they", "being-in-theworld [becomes] visible in its everydayness and averageness" (Heidegger, 1996:121). Now that it sees its condition, Dasein can clear away the "covering and obscurities" that prevent it from grasping itself. To become authentic, Dasein must "see through" the world of the "they" and realise itself, without forgetting that the being of averageness and everydayness is also a necessary and real way of being in the world. Although Dasein is certainly part of the everydayness of being, this should not limit Dasein's being to everydayness. Heidegger (1996:122) expresses it as follows: "Authentic beingone's-self is not based on an exceptional state of the subject, a state detached from the they, but is an existentiell modification of the they as an essential existentiall." The presence of the "they" can never be escaped, but their pressures and dictates need not be succumbed to either. Rather, grasping one's own Dasein opens up existential possibilities that are not limited by the dictates of the "they", but depend solely on the choice and possibilities of the individual.

This struggle with conformity, individuality and limitation is exemplified in the protagonist of Eliot's poem, Prufrock, who suffers from a constant, pervasive obsession with the perceptions and precepts of the "they". This obsession contributes to and compounds his inauthentic state. The pervasive tone of inauthenticity is immediately set by the title. The poem is named as a love-song - but then does not refer to love again. This ironic tone is as unrelenting as Prufrock is himself in his constant indecision and revision. The opening stanza of the poem is as follows:

Let us go then, you and I,

When the evening is spread out against the sky

Like a patient etherised upon a table;

Let us go, through certain half-deserted streets,

The muttering retreats

Of restless nights in one-night cheap hotels

And sawdust restaurants with oyster-shells: 
Streets that follow like a tedious argument

Of insidious intent

To lead you to an overwhelming question ...

Oh, do not ask, 'What is it?'

Let us go and make our visit

(Eliot, 1963:13.)

In this opening extract there is a sense of hopelessness and uncertainty, of angst. The two companions, one Prufrock and the other an unidentified male or female partner, seem existentially lost among the "half-deserted streets". They wander among and form part of the "they", considering if there is more to the world they inhabit than it seems to offer. The reader is confronted with an anonymous threat of plurality in the events that are described, in the "restless nights", "cheap hotels", "sawdust restaurants", "oyster shells" and "streets". The description gives the impression that this has all happened innumerable times before, the events of this life resembling a "tedious argument of insidious intent". Their repetition has begun to reveal something immoral, harmful and empty about this particular banal, everyday existence. There is an underlying lechery in "cheap hotels", an attempt to conceal everydayness in the supposed extravagance of "oyster shells" and a sense of hopelessness in the wandering of the "half-deserted streets". Eliot captures the portentous nature of Heidegger's "they", an anonymous force exuding from the everydayness and averageness of existence, a force that threatens to swallow the "us" in this first passage.

The opening phrase, "Let us go then", contributes to this general mood of tediousness and indicates Prufrock's resignation to his fate, as if at the beginning of the poem he has already foreseen and accepted the manner in which it ends. As the protagonist and voice of the poem, he beckons his companion and the reader to wander with him to glimpse, perhaps even to partake of these "half-deserted streets" and the sordid realities they depict.

The journey brings Prufrock to no certainty or answers, but instead culminates in Prufrockian angst, which is something constant throughout the poem. In Heideggerian terms, Prufrock is in constant tension between the "they", his own inauthenticity and the realisation of the possibility of his gaining his authentic self; as the poem will show, this is something he unfortunately never manages. This constant tension is oppressive to the point of existential paralysis. At several points in the poem it rises to the surface in various manifestations of a question, the singular overwhelming question which offers to redeem Prufrock from his inauthentic self. The question is 
overwhelming because it is so existentially important for Prufrock that he is in awe of asking it. It discloses the distinctive moment in an individual's life that distinguishes him from all others. Thus what faces Prufrock is the possibility of his own authenticity, which he is constantly on the verge of grasping, but which he never does.

In the instance in the first stanza the impulse to articulate the question is immediately suppressed by the lines "Oh, do not ask, "What is it?" The question is put off as Prufrock seems to immediately depart on a visit. The promise of the moment is substituted by the distraction, which allows Prufrock to forget himself and succumb to the blanketing, protective immersion offered by the "they". The visit is the subterfuge he needs to distract himself from himself. The momentary tension evaporates and, almost effortlessly, Prufrock slips back into everyday, inauthentic conformity.

The critical delaying of an honest answer to the question continues throughout the poem. The question hovers on the borders of Prufrock's consciousness, threatening to rise to full articulation at various points, appearing half-formed in lines like

And indeed there will be time

To wonder, 'Do I dare?'

or

Do I dare

Disturb the universe?

or

To have squeezed the universe into a ball

To roll it towards some overwhelming question

(Eliot, 1963:14, 16.)

The question never rises fully because of the "hundred indecisions ... and revisions" (Eliot, 1963:14) that Prufrock makes under the pressure of the "they", who influence his every decision and in the end become the reason for his indecision. The strength of this influence appears in his constant awareness of their insidious voice in his consciousness:

Time to turn back and descend the stair, With a bald spot in the middle of my hair (They will say: 'How his hair is growing thin!')

My morning coat, my collar mounting firmly to the chin, 
My necktie rich and modest, but asserted by a simple pin -

(They will say: 'But how his arms and legs are thin!')

And further:

And I have known the eyes already, known them all -

The eyes that fix you in a formulated phrase,

And when I am formulated, sprawling on a pin,

When I am pinned and wriggling on the wall,

Then how should I begin

To spit out all the butt-ends of my days and ways?

And how should I presume?

(Eliot, 1963:14.)

Prufrock's Dasein stands in subservience to the "they". He attempts to be himself, with his bald spot and his necktie, yet always feeling on public display he is acutely anxious about what "they" will say about him. This obsession with the "they" effectively prevents him from disclosing and realising the possibility of his own authentic self.

Perhaps the most disturbing aspect of this is that Prufrock is conscious of it; as he says, "I have known the eyes already, known them all". He is aware of how he is levelled down and averaged out, but remains unable to force the moment to its crisis and face the "overwhelming question". He feels his inauthentic state of existence, but cannot break from it. The hopeless indignity of this position is captured in the image of Prufrock as an insect "sprawling on a pin", prepared for dissection. Rather than facing the crisis, he mutters excuses for himself, blaming the entrapment he himself consents to, like a smoker who spits out his latest butt-end to complain about his cough. The mingled violence and subservience of the lines convey Prufrock's simultaneous resentment of and submission to the "they".

The intensity of his struggle suggests the profound importance of authenticity. The question it poses is truthfully of life and death significance, for being-towards-death is another of Dasein's existentials. Authentic Dasein is able to face the inescapable fact of its own death steadily. Only this allows it to live its own life fully. As the poem progresses we see Prufrock using several different tactics to avoid confronting this fact. Sometimes he uses procrastination and delay, as in the lines:

There will be time, there will be time

To prepare a face to meet the faces that you meet;

There will be time to murder and create,

And time for all the works and days of hands, 
That lift and drop a question on your plate

(Eliot, 1963:14.)

Time becomes an excuse to waste more time, for there will always be more time. Time allows Prufrock to keep up the pretence of his dull life, allows him to prepare a face to meet other faces, to average himself out to blend in with the "they" in a world in which murder and creation are equated indifferently. In this world Prufrock levels down the life which he has not yet lived:

For I have known them all already, known them all Have known the evenings, mornings, afternoons,

I have measured out my life with coffee spoons

(Eliot, 1963:14.)

Even doled out in this diminutive measure, however, time cannot last forever. Not all his evasions can save him from having to face the eventuality of his death.

I am no prophet - and here's no great matter;

I have seen the moment of my greatness flicker,

And I have seen the eternal Footman hold my coat, and

snicker,

And in short, I was afraid.

(Eliot, 1963:16.)

He reduces his moment of authenticity, "the moment of [his] greatness", to a brief insignificant instant by contrasting it with the eternity of death, and rather than finding resolve in this knowledge he can only confess to being afraid.

This cowardice shapes another vivid image that glances through Prufrock's mind, that of the ocean floor. In the crammed moment of all the busyness, distraction, dithering, shallowness, superficiality and uncertainty of Prufrock's life and thoughts, he suddenly thinks,

I should have been a pair of ragged claws

Scuttling across the floors of silent seas.

(Eliot, 1963:14.)

The calm of the ocean floor is an image of escape for Prufrock from the "they" and the reality that inhibits and suffocates him. This peaceful image and its calming effect on his crisis may initially seem positive, but it is mistaken and cowardly. It represents an impossible retreat; rather than fighting free of the "they" Prufrock resorts to dreaming of being an isolated, insignificant crustacean, scuttling across the empty ocean floor. Though Prufrock desires this escape, 
it will not bring him nearer to his authentic self; instead he substitutes one form of inauthenticity for another. The image of the ocean offering him escape recurs in the poem, connected to the Heidegger's concept of "idle talk", to which we now turn.

\section{Idle talk (Gerede)}

In Being and time Heidegger (1996:156) argues that an awareness of what constitutes the "they" helps to reveal to Dasein the nature of its own thrownness, of its initial inauthentic being in the world, so that it can identify the factors that maintain this state. One such factor is what he calls Gerede, "idle talk". This term is related to the "they" and authenticity, and is very useful in this reading of Prufrock.

In his investigation to disclose what constitutes our everyday being with others, Heidegger develops "idle talk" as an important everyday existential characteristic of the "they". "Idle talk", which could be rendered "derivative talk", is the way average everyday communication of the "they" occurs. Steiner (1989:7) refers to this phenomenon as "vacuous 'high gossip"', which we use as a pretence, to make ourselves appear busy and well informed. Schatzki (2005:243) points out that Heidegger's discussion of idle talk becomes a thinly veiled denunciation of everyday chatter. Like the "they" to which it is attributed, idle talk is a "dubious human universal".

As Heidegger (1996:157) explains it, idle talk is a discussion in which the speakers have no genuine understanding of what is discussed, no "primordial understanding" of the topic. The opposite of idle talk is discourse (Rede), which is communication involving genuine understanding. However, because of the general superficiality and averageness that permeates the everydayness of Dasein, this genuine understanding through discourse often does not take place. Dasein does not "communicate in the mode of a primordial appropriation of this being, but communicates by gossiping and passing the word along" (Heidegger, 1996:158). This is idle talk: the discussion is superficial, based on the average, everyday understanding of Dasein. People can engage in this kind of banter because they share the same language and a similar frame of reference.

Idle talk is not innocuous. What is talked about becomes widely accepted and gains authority, yet remains completely groundless in its essence. Essentially it "is the possibility of understanding everything without any previous appropriation of it", and herein lies its danger. Beliefs that are in fact groundless and without any real content can become prevalent in society. Because the "they" say so, these be- 
liefs are regarded as authoritative and influence Dasein's behaviour and beliefs. Heidegger (1996:158-159) writes that "when Dasein maintains itself in idle talk, it is - as being-in-the-world - cut off from the primary and primordially genuine relations of being toward the world". Any genuine, open and reciprocal understanding between human beings is closed off if they are continuously engaged in or engulfed by idle talk. This is certainly a problem Prufrock is aware of but cannot escape from, as will be discussed shortly.

Although Heidegger does not emphasise it explicitly, being open in discourse and facilitating genuine understanding on the one hand, and being engaged in superficial idle talk on the other, are categories that fit neatly inside the definitions of authentic and inauthentic modes of being respectively. This is not always the case and the relationship can become complex but for the most part being busy with idle talk implies subscribing to the precepts of the "they", which is essentially inauthentic.

Eliot, in Prufrock, strongly suggests the prevalence in society of Heidegger's "idle talk". Prufrock is intensely aware of it, yet unable to elude it. The relevant passage is short yet it admirably encapsulates this complex notion, suggesting the continual shadowy presence of the "they" and its accompanying gossip.

In the room the women come and go

Talking of Michelangelo.

(Eliot, 1963:13.)

The lines appear in exactly the same form further on in the poem, the deliberate repetition creating the impression that wherever Prufrock goes there seem to be women talking of Michelangelo. Their discussion of the artist seems rather careless and indifferent, for the phrase "come and go" suggests the passing throw-away nature of this conversation; it is Steiner's "vacuous 'high gossip"'. The scene become metaphoric for the inauthentic mode of Prufrock's existence, epitomised in these women engaged in this banter.

These lines are pivotal in Prufrock and embody the unavoidable presence and influence of the "they" throughout the poem. Their talk pervades Prufrock's consciousness, as we have noted before, and becomes the key factor preventing him from grasping himself. He cannot even escape it in his imaginary refuge in the ocean for the poem ends here. 
We have lingered in the chambers of the sea

By sea-girls wreathed with seaweed red and brown

Till human voices wake us, and we drown.

(Eliot, 1963:17.)

From his dream of a responsibility-free, unconscious existence, Prufrock returns to the world of human voices to drown in the idle talk of the "they". His condition of tension cannot be so easily escaped, because his obsession with his inauthentic state has roots deeper than the "they" and the world to which he is condemned. Prufrock's own "angst" is the major cause of his inauthentic state of being, compounded by the presence of the "they".

\section{Angst}

This angst is another existential of Dasein's being-in-the-world. 8 The absorption of Dasein in the world of the "they" is like a flight of Dasein from the authentic potentiality it has for being itself. The problem with this flight is that it cannot outrun angst, because "that about which one has Angst is being-in-the-world as such" (Heidegger, 1996:172-174). Angst is not situated in a particular phenomenon or moment; rather, it is centred nowhere, which is precisely why it is so threatening. Heidegger (1996:174-175) emphasises that this "nowhere"

... does not mean nothing ... What is threatening cannot approach from a definite direction within nearness, it is already 'there' - and yet nowhere. It is so near that it is oppressive and stifles one's breath - and yet it is nowhere ... What oppresses us is not this or that, nor is it everything objectively present together as a sum, but the possibility of things at hand in general, that is, the world itself.

Angst can be translated in various ways. The Macquarrie and Robinson translation of Being and time (Heidegger, 1962), uses anxiety, while the Stambaugh translation, which I am using, keeps the word untranslated as Angst. Macquarrie and Robinson note that the German word Angst is rendered "dread" in translations of Kierkegaard and in some discussions on Heidegger, and admit that in some contexts in Being and time "uneasiness" or "malaise" would be perhaps more appropriate than anxiety (Heidegger, 1962:227). So to avoid over-simplifying Heidegger's complex meaning, which conveys a more profound sense of existential anxiety than the English use of "anxiety", I will follow Stambaugh, but write the word in small letters only. The reason I do this is because the word angst is used, although not widely, in English speech and is entered in the Concise Oxford Dictionary (Pearsall, 1999). 
Angst is deeply disconcerting, and in this lies both a danger and a promise. The danger is that "it takes away from Dasein the possibility of understanding itself", the disease preventing any deeper searching. Conversely, however, angst can also prompt searching by showing itself as a feeling of uncanniness, of "not-being-athome". As part of the average, everydayness of being, Dasein is "at home", absorbed in "the everyday publicness of the 'they' which brings tranquillized self-assurance, 'being-at-home' with all its obviousness". Angst removes Dasein from this tranquil self-assurance, causing everyday familiarity to collapse. This sensation is unnerving and unsettling, but it offers the possibility of a distinctive disclosure. Angst individualises, by fetching Dasein back from its immersion in the "they" and revealing "to it authenticity and inauthenticity as possibilities of its being" (Heidegger, 1996:176-178).

Thus, Prufrock's behaviour among other people and his imagined ocean escapes can be understood as a flight from the possibility of his authentic self into the "they"-self, a flight rooted in his existential angst. The irony of course is that as long as Prufrock is in the world he cannot escape his angst, because it arises in his very being as Dasein, which he cannot outrun or escape. He is always himself, even if only a resented, cowardly version. Thus the cause of his angst is essentially the inability to reconcile the way the world is with the way he would like to relate to the world and himself.

The regressive and desperate passage of the poem reveals Prufrock trapped within his angst, is compounded by the authority of the "they" whom he feels he must constantly oblige. Angst both prompts and paralyses him in grasping towards his authentic self. Both these intentions appear in a pivotal moment in the poem.

And indeed there will be time

To wonder, 'Do I dare?' and, 'Do I dare?'

Time to turn back and descend the stair...

Do I dare

Disturb the universe?

In a minute there is time

For decisions and revisions which a minute will reverse

(Eliot, 1963:14.)

The question is starkly grasped in all its enormous import: "Do I dare / Disturb the universe?" If the answer is yes, the course of the poem and of Prufrock's life will change irreversibly. Yet it is suffocated and insulated in the terror and prevarication that this enormity brings with it; once the step is taken Prufrock will be unable to "turn back and 
descend the stair", or to make those "revisions which a minute will reverse". This is a true experience of angst under both its aspects, both revealing Dasein ownmost potentiality for being, which is being free to choose itself, and disclosing this realisation as overwhelming and dreadful.

So the crisis collapses. The awesome possibility dissipates, the bold, though unfulfilled "daring" disappears, and Prufrock appears to lose all courage. Sliding away from the unsettling possibility of "disturbing the universe", he takes refuge in insignificant decisions exalted into grandiose uncertainties: "Shall I part my hair behind? Do I dare to eat a peach?" (Eliot, 1963:17). This elevation of insignificant actions to the same level as "disturbing the universe" entirely deflates his pursuit of authenticity.

As the poem ends, as Prufrock resigns himself to drown in human voices, in the background we can distinctly hear the hum of the women who come and go, talking of Michelangelo. He gives up the possibility of coming to terms with his own existence and remains in the arid chattering world of the "they". Yet his failure is not final. In the poem as a whole, in raising the vision of authentic being in all its unsettling power, as in his broader project, Eliot joins Heidegger in diagnosing the promise behind the angst of Dasein and inviting us to live beyond Prufrock's example.

\section{Conclusion}

In conclusion, Eliot's The love song of J. Alfred Prufrock, analysed using concepts from Heidegger's Being and time, reveals some desperate truths about the state of the Western human condition in the early twentieth century, and the promise implicit in these truths. The existentials that Heidegger discusses, which ontologically constitute Dasein, become the means of diagnosing the Prufrockian dilemma: how is it that one should be? The lasting influence of the poem and the singular importance of Being and time affirm the enduring and profound nature of this question.

This is just one interesting example of many other points of intersection between the thought of Eliot and Heidegger. Others include their shared interest in mysticism, their interest in Eastern thought, their disillusionment with the modern world and their manner of response to this disillusionment, the importance both placed on the redemptive quality of art, especially poetry, as a response to the growing threat of material nihilism, their strong critiques against technology, and their emphasis on homogenous communities. 
Thus the discussion in this article is merely the tip of a comparative iceberg. A secondary aim is thus to suggest the possibility of a broader discussion of this deeper concordance. Something in the imaginative, intellectual, social and cultural climate of the early twentieth century led both men to notice similar problems and trends and to form sometimes strikingly similar judgements about them. While the diagnosis of what exactly this something is, is beyond the scope of this article, the interrelating of Prufrock and Being and time strongly suggests its presence.

One immediate objection to this may be to say that, since Heidegger and Eliot shared the same historical context and were educated in a similar philosophical tradition, of course they would say similar things. What is the point then of tracing these similarities? I would respond that Eliot and Heidegger are no mere ordinary representatives of their shared historical period. Eliot is almost universally agreed to be the greatest poet of the literary modernist movement and one of its foremost theorists. He is of towering significance in the aesthetic and moral life of the twentieth century, the first half of which has even been called the Age of Eliot (Brooker, 1994:238). Heidegger, in his masterly engagement with the philosophical problems of modernity, the same problems that gave rise to Eliot's literary modernism, has secured himself an unequalled position among twentieth-century philosophers. Thus, we will arguably gain a far richer understanding of this period and its consequences for ours, if we examine not only each of these central thinkers in isolation, but also each in the light of the other and the fruitful interrelation of their ideas.

\section{List of references}

BROOKER, J.S. 1994. Mastery and escape: T.S. Eliot and the dialectic of modernism. Amherst: University of Massachusetts.

CAPUTO, J.D. 1999. Heidegger. (In Critchley, S. \& Schroeder, W.R., eds. A companion to continental philosophy. Malden: Blackwell. p. 223-233.)

CARMAN, T. 2007. Authenticity. (In Dreyfus, H.L. \& Wrathall, M.A., eds. A companion to Heidegger. Malden: Blackwell. p. 285-296.)

CHILDS, D.J. 2001. From philosophy to poetry: T.S. Eliot's study of knowledge and experience. London: Athlone.

DAVIDSON, H. 1985. T.S. Eliot and hermeneutics: absence and interpretation in The waste land. Baton Rouge: Louisiana State University Press.

ELIOT, T.S. 1963. The love song of J. Alfred Prufrock. (In Eliot, T.S. Collected poems 1909-1962. London: Faber \& Faber. p. 13-17.)

ELIOT, T.S. 1964. Knowledge and experience in the philosophy of F.H. Bradley. London: Faber \& Faber. 
ELIOT, T.S., ed. 1967. A commentary: the Criterion. Vol. 12. London: Faber \& Faber.

FRITSCHE, J. 1999. Historical destiny and national socialism in Heidegger's Being and time. Berkeley: University of California Press.

GORNER, P. 2007. Heidegger's Being and time: an introduction. Cambridge: Cambridge University Press.

HEIDEGGER, M. 1962. Being and time. Trans. by J. Macquarrie \& E. Robinson. Malden: Blackwell.

HEIDEGGER, M. 1996. Being and time. Trans. by J. Stambaugh. New York: State University of New York Press.

HEIDEGGER, M. 2001. Poetry, language, thought. Trans. by A. Hofstadter. New York: HarperCollins.

INWOOD, M. 1999. A Heidegger dictionary. Oxford: Blackwell.

JAIN, M. 2004. T.S. Eliot and American philosophy: the Harvard years. Cambridge: Cambridge University Press.

KNAPP HAY, E. 1982. T.S. Eliot's negative way. Cambridge: Harvard University Press.

MULHALL, S. 1996. Heidegger and Being and time. London: Routledge.

PEARSALL, J., ed. 1999. The Concise Oxford dictionary. 10th ed. New York: Oxford University Press.

RABATÉ, J.-M. 1994. Tradition and T.S. Eliot. (In Moody, A.D., ed. The Cambridge companion to T.S. Eliot. Cambridge: Cambridge University Press. p. 210-222.)

SAFRANSKI, R. 1999. Martin Heidegger: between good and evil. Trans. by E. Oswald. Cambridge: Harvard University Press.

SCHATZKI, T.R. 2005. Early Heidegger on sociality. (In Dreyfus, H.L. \& Wrathall, M.A., eds. A companion to Heidegger. Malden: Blackwell. p. 233-247.)

SCHWARTZ, S. 1985. The matrix of modernism: Pound, Eliot and early twentieth-century thought. Princeton: Princeton University Press.

SEYMOUR-JONES, C. 2001. Painted shadow: the life of Vivienne Eliot. London: Robinson.

SHUSTERMAN, R. 1994. Eliot as philosopher. (In Moody, A.D., ed. The Cambridge companion to T.S. Eliot. Cambridge: Cambridge University Press. p. 31-47.)

SPANOS, W.V. 1978. Hermeneutics and memory: destroying T.S. Eliot's Four quartets. Genre, 11(4):523-573.

SPANOS, W.V., ed. 1979. Martin Heidegger and the question of literature: toward a postmodern literary hermeneutics. Bloomington: Indiana University Press.

STEINER, G. 1989. Real presences. Chicago: University of Chicago Press.

VAN BUREN, J. 1994. The young Heidegger: rumour of the hidden king. Bloomington: Indiana University Press.

WILSON, E. 1995. On the way to the still point: Eliot's Four quartets and Martin Heidegger. Yeats Eliot review, 13(3 \& 4):56-63.

YOUNG, J. 1997. Heidegger, philosophy, Nazism. Cambridge: Cambridge University Press.

YOUNG, J. 2003. The death of God and the meaning of life. London: Routledge. 


\section{Key concepts:}

authenticity

Das Man

Eliot, T.S.

Heidegger, Martin

Prufrock

\section{Kernbegrippe:}

Das Man

Eliot, T.S.

Heidegger, Martin

outentisiteit

Prufrock 